\title{
RESSUSCITAÇÃO CARDIOPULMONAR: UMA ABORDAGEM ATUALIZADA
}

\author{
Marilaine M. de Menezes Ferreira
}

Brisa Santos Silva

Patrícia Moura Bahiana

Renata Luiza de Lima Costa

Enfermeira, Mestre em Família na Sociedade Contemporânea. Professora Assistente do curso de Enfermagem da Escola Bahiana de Medicina e Saúde Pública.

Graduanda do curso de Enfermagem da Escola Bahiana de Medicina e Saúde Pública (EBMSP).

Graduanda do curso de Enfermagem da Escola Bahiana de Medicina e Saúde Pública (EBMSP).

Graduanda do curso de Enfermagem da Escola Bahiana de Medicina e Saúde Pública (EBMSP).

\author{
Rosemeire Oliveira Moreira Menezes \\ Graduanda do curso de Enfermagem da \\ Escola Bahiana de Medicina e Saúde Pública \\ (EBMSP).
}

\begin{abstract}
RESUMO
Dados estatísticos mostram que a Parada Cardiorrespiratória é a principal causa de morte nos Estados Unidos, Europa e Canadá, e a sua chance de sobrevivência, após o evento, varia de $2 \%$ a $49 \%$, dependendo do ritmo cardíaco original e do início precoce de reanimação. O objetivo do artigo é descrever a ressuscitação cardiopulmonar de acordo com as diretrizes da American Heart Association; identificando suas possíveis causas, os sinais clínicos, a atuação do leigo na situação de emergência e o uso do desfibrilador automático. Esta pesquisa bibliográfica abordou estudos publicados nos últimos sete anos, por intermédio de buscas sistemáticas utilizando banco de dados eletrônicos (LILACS e SciELO). Alguns Resultados apontam para a necessidade de um conhecimento mínimo para uma abordagem rápida e a possível reversão da Parada Cardíaca com melhores chances de sobrevida. Para isso há o Suporte Básico de vida, tido como a primeira abordagem à vítima, abrangendo etapas que podem ser iniciadas fora do ambiente hospitalar e que visam aumentar a sobrevida por morte súbita. Para que esse socorro seja realizado de forma efetiva, há a necessidade de capacitação da população leiga, para que esteja familiarizada com as técnicas e as prioridades no atendimento. Além disso, há a necessidade de atentar para a ética verificando qual o amparo da lei para a decisão de não reanimar. Recomendase uma difusão de informações sobre como agir nesta situação, já que a educação em saúde é uma ferramenta indispensável neste processo.
\end{abstract}

Palavras-chave: Ressuscitação cardiopulmonar; Parada cardíaca; Educação em saúde.

\section{RESUSCITATIVE CARDIOPULMONARY: UPDATED APPROACH}

\section{ABSTRACT}

Statistical data show that cardiac arrest is a leading cause of death in the United States, Europe and Canada and the chance of survival after the event ranges from $2 \%$ to $49 \%$, depending on the original heart rate and early resuscitation procedures. The aim of this paper is to describe cardiopulmonary resuscitation according to the guidelines of the American Heart Association, identifying its possible causes, clinical signs, the role of the laity in emergency and use of defibrillator. This literature has addressed studies published in the last seven years, through systematic searches using electronic databases (LILACS and SciELO). Some results point to the need of a minimum knowledge for a quick approach and possible heart failure reversal with better chances of survival. 
For instance, Basic Life Support is regarded as the first approach to the victim, including steps that can be initiated outside the hospital environment and aimed to increase survival from sudden death. For this rescue be done effectively, there is need for training of the lay population on familiarity with the techniques and priorities in attendance. In addition, there is the need to pay attention to the ethical checking about law protection for the decision not to resuscitate. Is recommended dissemination of information on how to act in this situation, since the health education is an indispensable tool in this process.

Keywords: Cardiopulmonary resuscitation; Cardiac arrest; Health education.

\title{
RESUCITACIÓN CARDIOPULMONAR: ENFOQUE ACTUALIZADO
}

\begin{abstract}
RESUMEN
Datos estadísticos muestran que el paro cardiaco es una causa principal de muerte en los Estados Unidos, Europa y Canadá y sus posibilidades de supervivencia, después del evento, varía de $2 \%$ a $49 \%$, dependiendo de la frecuencia cardíaca y la reanimación original de principios. El objetivo de este trabajo es describir la reanimación cardiopulmonar, según la Asociación Americana del Corazón, la identificación de las posibles causas, signos clínicos, el papel de los laicos en la emergencia y el uso del desfibrilador. Esta literatura se ha ocupado de los estudios publicados en los últimos siete años, a través de búsquedas sistemáticas utilizando las bases de datos electrónicas (LILACS y SciELO). Algunos resultados apuntan a la necesidad de un conocimiento mínimo para un enfoque rápido y posible reversión insuficiencia cardíaca con mejores posibilidades de supervivencia. Para ello existe el Soporte Vital Básico, considerado como el primer acercamiento a la víctima, incluidos los pasos que pueden iniciarse fuera del ámbito hospitalario y dirigidas a aumentar la supervivencia de la muerte súbita. Para este rescate se realiza efectivamente, existe la necesidad de formación de la población laica, que esté familiarizado con las técnicas y las prioridades en la asistencia. Además, existe la necesidad de prestar atención a la comprobación de ética que la protección de la ley para la decisión de no reanimar. Se recomienda la difusión de información sobre cómo actuar en esta situación, ya que la educación sanitaria es una herramienta indispensable en este proceso.
\end{abstract}

Palabras clave: Reanimación cardiopulmonar; El paro cardiaco; Educación para la salud.

\section{INTRODUÇÃOO}

A Parada cardiorrespiratória (PCR) é a cessação abrupta da função mecânica cardíaca, ocorrendo, consequentemente, a parada dos outros órgãos vitais devido à falta de oxigenação, e, por conseguinte, da respiração. ${ }^{(1)}$ As principais causas da PCR no Brasil são as doenças do aparelho circulatório, ocasionando a morte em 32\% das vítimas acometidas. Segundo dados da OMS, foram 17,5 milhões de óbitos por doenças cardiovasculares (30\%) em 2005, e mais da metade ocorreram de forma súbita. A cardiopatia isquêmica se sobressai entre as doenças, representando uma das principais causas de morte atuais. ${ }^{(1,2)}$

Dados estatísticos mostram que a Parada cardiorrespiratória é a principal causa de morte nos Estados Unidos, Europa e Canadá ${ }^{(1,2)}$ e a sua chance de sobrevivência, após o evento, varia de $2 \%$ a $49 \%$, dependendo do ritmo cardíaco original e do início precoce de reanimação. ${ }^{(3)}$ Devido a isso, a necessidade de haver o conhecimento teórico e prático e um atendimento eficaz iniciado o mais rápido possível, está entre os determinantes para o sucesso da Ressuscitação Cardiopulmonar (RCP). ${ }^{(4,5)}$ 
No fim do império Romano, em 476 a.C, os métodos de ressuscitação variaram desde aplicação de objetos quentes ou queimantes sobre o abdômen, até a flagelação chicoteando-se com urtiga. Porém, foi apenas em 1960 que a RCP passou a ser considerada técnica científica, sendo o Dr. Archer S. Gordon, um dos pioneiros da reanimação moderna. ${ }^{(6,7)}$

O Suporte Básico de vida (SBV) é tido como a primeira abordagem à vítima, abrangendo etapas que podem ser iniciadas fora do ambiente hospitalar e que incluem a abertura de vias aéreas, ventilação e circulação. Por isso a sua importância, visando melhorar a sobrevida na morte súbita cardíaca. ${ }^{(8,9)}$

Para que esse socorro seja realizado correto e rapidamente, há a necessidade de capacitação da população leiga, para que a mesma esteja familiarizada com as técnicas e prioridades no atendimento. $\mathrm{O}$ reconhecimento da PCR e a ligação para o socorro o mais breve possível, previnem a deterioração miocárdica e cerebral. ${ }^{(9,10)}$

A primeira técnica de desfibrilação com êxito ocorreu em 1933, em animais. E em seguida, em 1947, foi aplicada uma corrente elétrica diretamente no coração humano usando corrente alternada. E esse é outro ponto importante a ser abordado, pois, é fundamental o aprendizado para a utilização do DEA por leigos, já que, o mesmo encontra-se a disposição em locais públicos. ${ }^{(6,10)}$

Além disso, há a necessidade de atentar para a ética profissional na RCP, no sentido de manter ou desistir da manobra. As ordens de não ressuscitação ainda não possuem amparo legal, mas necessitam de destaque, para um esclarecimento e retirada de dúvidas. ${ }^{(11,12,13)}$

O objetivo deste artigo é descrever analiticamente a ressuscitação cardiopulmonar de acordo com as diretrizes da American Heart Association; identificando suas possíveis causas, os sinais clínicos, a atuação do leigo na situação de emergência, e o uso do desfibrilador automático.

\section{MATERIAL E MÉTODOS}

Trata-se de uma pesquisa bibliográfica com busca de artigos de revistas indexadas e dissertações nas bases de dados LILACS e SciELO, por meio da Biblioteca Virtual em Saúde (BVS). Para a seleção de artigos foram utilizados o formulário básico e as palavras chave: RCP; Parada Cardiorrespiratória; história; DEA; SBV.

Inicialmente foram selecionados os trabalhos que apresentassem textos na íntegra em português ou espanhol, publicados de 2000 a 2012, com títulos ou resumos que indicavam 
uma aproximação com o tema deste estudo e que foram considerados pertinentes, sendo encontradas 47 (quarenta e sete) publicações. Destas, foram selecionados 19 (dezenove). Foram excluídos os artigos que não atendiam aos objetivos propostos pelo estudo. Além disso, a inclusão foi limitada aos publicados a partir do ano de 2000 levando-se em consideração os artigos que utilizavam os dois últimos protocolos da AHA. Além disso, utilizou-se o Protocolo da AHA publicado em 2010.

\section{RESULTADOS E DISCUSSÕES}

A partir da leitura sistemática dos artigos selecionados optou-se pela apresentação dos resultados em categorias: Fatores predisponentes e diagnóstico da PCR; O leigo e o SBV; O uso do DEA no SBV; Aspectos éticos.

\section{FATORES PREDISPONENTES E DIAGNÓSTICO DA PCR}

A Parada cardiorrespiratória é uma anormalidade grave, que resulta da cessação de todos os sinais elétricos de controle no coração. ${ }^{(14)}$ Os sinais clássicos que acompanham a PCR são: a perda da consciência devido à diminuição da circulação cerebral; os pulsos carotídeos tornam-se ausentes, assim como os movimentos respiratórios. O diagnóstico clínico imediato da Parada cardiorrespiratória é feito através da avaliação destes sinais clássicos, já o diagnóstico mediato é somente possível em um ambiente que permita a monitorização cardíaca, através do eletrocardiograma (ECG), para a identificação de arritmias fatais com fibrilação ventricular, taquicardia ventricular e assistolia. ${ }^{(15)}$

Através de um estudo realizado em Salvador, no qual foram analisados 452 pacientes que receberam reanimação, concluiu-se que a enfermidade cardiovascular foi a principal causa de parada, representando $50 \%$ dos casos, seguido de trauma (17\%) e pneumopatia. ${ }^{(16)}$

O Instituto Dante Pazzanese de Cardiologia, em São Paulo, seguindo as orientações da American Heart Association, que na época descrevia as três modalidades da parada cardíaca como fibrilação ventricular, assistolia e dissociação eletromecânica, preconizou que a parada respiratória fosse demarcada como a modalidade inicial, quando resultasse da perda de pulso, a qual necessitaria de ressuscitação cardiopulmonar. ${ }^{(17)}$

Com base em uma análise multivariada nos fatores predisponentes para uma parada cardiorrespiratória que demonstraram resultados estatísticos significativos, identificou-se 
como doenças de base a cardiopatia congênita acianogênica, a insuficiência renal crônica e o cor pulmonale crônico; nas causas de paradas cardiorrespiratórias referenciaram-se a insuficiência miocárdica, o Acidente Vascular Cerebral e a crise anóxica. ${ }^{(17)}$

\section{O LEIGO E O SBV}

O Suporte Básico de Vida é o conjunto de medidas que formam as etapas de socorro da RCP, e pode ser iniciado fora do ambiente hospitalar pela população em geral, desde que seja treinada e/ou possua conhecimento para realizar o procedimento. Esse método de socorro permite aumentar a sobrevida e diminuir as sequelas devido à Parada Cardiorrespiratória. ${ }^{(9)}$

A abordagem rápida do leigo, que reconhece uma Parada Cardiorrespiratória e chama o socorro previne a deterioração miocárdica e cerebral. ${ }^{(9)}$ De acordo com a AHA, caso a pessoa presente no local não tiver treinamento em RCP, a mesma deverá aplicar apenas as compressões torácicas, no centro do tórax, de maneira forte e rápida. ${ }^{(18)}$

Um estudo realizado na cidade de São Paulo, com o intuito de identificar o conhecimento da população leiga sobre o SBV, observou que, dos 385 indivíduos da amostra, apenas $16,4 \%$ responderam corretamente quanto à realização da manobra para facilitar a respiração. As respostas dos leigos a respeito da técnica de respiração boca-a-boca obtiveramse 9,9\% das respostas corretas; em resposta a realização da compressão torácica, 47,5\% não realizariam; $14,5 \%$ sabiam posicionar o paciente corretamente e $8,8 \%$ sabiam a região do corpo na qual se realiza a compressão. Em relação à quantidade de compressões realizadas, $64,7 \%$ referiram não saber. ${ }^{(9)}$ Os autores do estudo concluíram que os leigos podem prestar atendimento incorreto à vítima acarretando em prejuízos à reanimação por não apresentarem adequada informação e fundamentação das etapas do SBV.

As medidas de SBV são atualizadas periodicamente a cada cinco anos a partir do consenso de especialistas, baseado em evidências científicas, o que permite uma constante atualização das técnicas. De acordo com a American Heart Association, divulgado em 2010, as novas diretrizes visam proporcionar um atendimento de alta qualidade e ao mesmo tempo mais simplificado. ${ }^{(18)}$

No protocolo de 2010, houve a alteração da sequência de atendimento de A-B-C para C-A-B, recomendando o início das compressões torácicas antes das ventilações. Essa mudança visa um melhor resultado, já que as compressões torácicas fornecem fluxo sanguíneo e dados registrados demonstram que atrasos ou interrupções nas compressões 
torácicas reduzem a sobrevivência. Assim, tais atrasos ou interrupções devem ser minimizados ao longo de toda a ressuscitação. Considera-se também que se estiver presente apenas um socorrista no local de atuação, o C-A-B é melhor via de socorro, pois as compressões torácicas podem ser iniciadas quase imediatamente, ao passo que posicionar a cabeça e se posicionar e preparar para a respiração boca-a-boca exige certo tempo. ${ }^{(18)}$

Em relação ao procedimento "ver, ouvir e sentir", o mesmo foi retirado do processo, e a respiração deve ser rapidamente averiguada apenas com a observação da elevação do tórax no momento em que se observa os sinais de PCR. ${ }^{(18)}$

A frequência de compressões por minuto, que antes eram de "aproximadamente de 100", hoje se alterou para "no mínimo 100”. O número de compressões torácicas aplicadas por minuto durante a RCP é um fator determinante para o retorno da circulação e da sobrevivência com boa função neurológica. Na maioria dos estudos, a aplicação de mais compressões durante a ressuscitação está associada a uma maior sobrevivência. ${ }^{(18)}$

Além disso, essas compressões devem ser localizadas no esterno do adulto, e alcançarem uma profundidade de, no mínimo, duas polegadas ou cinco centímetros. Essa mudança deve-se ao fato de que anteriormente, criava-se uma faixa de profundidade, podendo ocasionar erros e confusões. Devido a isso, alterou-se o valor para um número exato. Ademais, essa profundidade de compressão é fundamental, pois criam fluxo sanguíneo principalmente por aumentarem a pressão intratorácica e comprimirem diretamente o coração. $^{(18)}$

\section{USO DO DEA NO SBV}

Desde 1992, a AHA desenvolveu o conceito de corrente de sobrevida, que preconiza uma série ordenada e encadeada de procedimentos durante o atendimento a uma Parada cardiorrespiratória. ${ }^{(19,20)}$ Atualmente a cadeia de sobrevivência é composta de cinco elos. Inclui-se o acesso rápido, reconhecendo a PCR e entrando em contato com o serviço de emergência/urgência, para obter ajuda; inicia-se a ressuscitação cardiopulmonar (RCP) rápida, dando prioridade as compressões torácicas; a desfibrilação rápida com a identificação e o tratamento da FV, a aplicação das técnicas do Suporte Avançado de Vida em Cardiologia (SAVC) e, por fim, o cuidados após a PCR. ${ }^{(5,18)}$ 
Ao presenciar uma PCR extra-hospitalar e havendo um desfibrilador elétrico automático (DEA/DAE) prontamente disponível no local, o socorrista deverá iniciar a RCP com compressões torácicas e usar o DEA/DAE o quanto antes. ${ }^{(18)}$

O DEA/DAE é um aparelho que reproduz para o socorrista o que é necessário ser feito, não requerendo um vasto conhecimento sobre o tema. Primeiramente devem-se remover as roupas do tórax da vítima e ligar o aparelho. Logo após, deve-se destacar as pás e colocálas sobre o tórax da vítima nas posições corretas. $\mathrm{O}$ aparelho pede para que não se encoste na vítima. Se o ritmo for desfibrilável, o choque será recomendado pelo aparelho e cabe ao socorrista acionar a tecla de choque. Se não, o aparelho anuncia que o choque não é recomendável, sendo necessárias as manobras cardíacas. ${ }^{(21)}$

O intervalo de tempo entre a perda da consciência e a desfibrilação é a variável mais importante para a reversão bem sucedida da FV a um ritmo normal. ${ }^{(10)}$

Ainda de acordo com a American Heart Association, a Ressuscitação cardiopulmonar e o uso de DEA/DAE por socorristas são recomendados para aumentar as taxas de sobrevivência em PCR súbita fora do âmbito hospitalar. As Diretrizes da AHA 2010 para $\mathrm{RCP}$ recomendam estabelecer programas de DEA/DAE em locais públicos nos quais existam grandes possibilidades de ocorrência de PCR. ${ }^{(18)}$

Um estudo realizado por Caffrey e colaboradores mostrou que leigos podiam usar desfibriladores externos automáticos e realizar RCP após 3 minutos de um vídeo autoexplicativo, em local público, exibidos a cada 30 minutos nos monitores de TV nas áreas de espera do aeroporto de Chicago. Esse vídeo indicava a disponibilidade dos DEA/DAE, explicava seu propósito e encorajava seu uso enquanto também eram distribuídos folhetos impressos. ${ }^{(8)}$

Além disso, em países como nos Estados Unidos, todos os estados promulgaram uma legislação para encorajar o uso do DEA/DAE pelo público leigo. Essa lei, denominada de Lei de Sobrevivência à Parada Cardíaca, oferece proteção judicial a socorristas leigos que utilizam o DEA/DAE e a empresas ou outras entidades ou indivíduos que compram um aparelho desse tipo para o acesso público. Em comunidades americanas, o uso do DEA/DAE por socorristas leigos proporcionou taxas de sobrevivência extraordinárias, de até $49 \% .^{(10)}$ 


\section{ASPECTOS ÉTICOS}

A medida de Reanimação visa a alternativa de reversibilidade da PCR, entretanto os princípios éticos devem ser considerados. ${ }^{(8,22)}$

De acordo com o artigo 135 do Código Penal, "Deixar de prestar assistência, quando possível fazê-lo sem risco pessoal, à criança abandonada ou extraviada, ou à pessoa inválida ou ferida, ao desamparo ou em grave e iminente perigo; ou não pedir, nesses casos, o socorro da autoridade pública: Pena - detenção, de 1 (um) a 6 (seis) meses, ou multa. Parágrafo único

- A pena é aumentada de metade, se da omissão resulta lesão corporal de natureza grave, e triplicada, se resulta a morte.".(23)

Caso a pessoa não se sinta preparada para a prestação do socorro, como, por exemplo, um leigo, o fato de chamar o socorro especializado já descaracteriza a ocorrência de omissão de socorro.

Além disso, o paciente tem pleno direito de recusar um determinado tratamento médico com fundamento no Título II (Dos Direitos e Garantias Fundamentais), presente no capítulo I (Dos Direitos e Deveres Individuais e Coletivos), artigo 5º, II da Constituição Federal, que reza que ninguém é obrigado a fazer ou deixar de fazer algo, salvo em virtude de lei. Dessa forma, a vítima tem o direito à recusa de atendimento. No caso, de não haver capacidade de responder pelos seus atos, por ser uma criança, estar inconsciente, a presença de familiares no ambiente os torna responsáveis pela vítima. Os mesmos podem recusar o atendimento. Caso contrário, quando não houver um responsável, deve-se prosseguir com os procedimentos, sempre arrolando testemunhas. ${ }^{(23)}$

É tido como ordens de não ressuscitar os sinais de morte e ausência de benefício fisiológico, porém essas decisões só cabem ao médico, decidindo interromper a RCP. A ordem judicial prévia, juntamente com a recusa do paciente, anteriormente citada, ordena o não prosseguimento da ressuscitação. ${ }^{(13,22)}$

Mesmo que não haja retorno da circulação e respiração, há a necessidade de chegada do socorro especializado, para decidir como proceder. ${ }^{(13)}$

A partir do socorro especializado, considera-se a ordem para não ressuscitar (ONR). Trata-se de um instrumento que pode ser empregado, através de formulários, com o intuito de orientar a não realização das manobras de RCP. Cada instituição tem uma forma de aplicá-la. (21) 
A AHA escreveu dilemas éticos sobre o tema, visando proteger os profissionais da área de saúde. Entretanto, visa-se a utilização do bom senso durante a tomada de decisões, procurando respaldo da ciência, as preferências do indivíduo ou de seus representantes, bem como pelas exigências legais e dos programas de ações locais. Um dos dilemas éticos da AHA é voltado para adultos que sofram PCR extrahospitalar e que estejam recebendo apenas SBV. Foi estabelecida a regra de SBV para encerramento de ressuscitação, que considera o encerramento do SBV antes do transporte por ambulância, se todos os seguintes critérios forem atendidos: PCR não presenciada pelo profissional do Serviço Médico de Emergência ou primeiro socorrista; Ausência de retorno de circulação espontânea após três ciclos completos de RCP e análises do DEA/DAE; Nenhum choque aplicado com o DEA/DAE. ${ }^{(18)}$

Todavia, no Brasil, não há uma legislação para isso, diferentemente de locais com Estados Unidos e no Chile. ${ }^{(12,13,22)}$

\section{CONCLUSÕES}

Umas das principais causas de agravo e morte da população mundial são as doenças cardiovasculares podendo levar a ocorrência de Parada Cardiorrespiratória. Logo, a PCR é uma situação que ocorre com considerável frequência na população, sendo muitas vezes em locais públicos com fluxo intenso de pessoas.

Tendo em vista a relevância e prevalência deste agravo, concluímos que se deve haver uma difusão de informações sobre como agir nesta situação não só entre os profissionais de saúde, mas também entre a população leiga. A educação em saúde é uma ferramenta indispensável neste processo, no sentido de viabilizar a sobrevida da vítima acometida por PCR a partir da atuação de leigos treinados utilizando as manobras do SBV preconizadas pelos Protocolos.

O DEA/DAE é um importante recurso para minimizar os agravos decorrentes da PCR por ritmos desfibriláveis, sendo imprescindível que este equipamento esteja disponível e com fácil acesso em locais públicos para que a população leiga treinada possa utilizá-lo sempre que necessário. 


\section{REFERÊNCIAS}

1 Sardo PMG, Dal Sasso, GTM. Aprendizagem baseada em problemas em ressuscitação cardiopulmonar: suporte básico de vida. Rev. esc. enferm. USP, 2008 [acesso em $2012 \mathrm{abr}$ 06]; 42 (4). Disponível em: <http://www.scielo.br/scielo.php?script=sci_arttext\&pid=S0080$62342008000400023 \& \operatorname{lng}=\mathrm{en} \& \mathrm{nrm}=\mathrm{iso}>$.

2 Clementino JO. Condutas de enfermagem frente à parada cardiorrespiratória no contexto pré-hospitalar. [on line]. 2011. [acesso em 2012 abr 06]

Disponível em: <http://www.webartigos.com/artigos/condutas-de-enfermagem-frente-aparada-cardiorrespiratoria-no-contexto-pre-hospitalar/65348/>.

3 Guimarães HP, Lane JC, Flato UAP et al. A história da ressuscitação cardiopulmonar no Brasil. Rev Bras Clin Med, 2009. [acesso em 2012 abr 06]. Disponível em:

<http://www.ipatre.com.br/download/rcp-brasil.pdf $>$.

4 Lima SG et al. Educação Permanente em SBV e SAVC: impacto no conhecimento dos profissionais de enfermagem. Arq. Bras. Cardiol., 2009 [acesso em 2012 abr 06]; 93(6). Disponível em: <http://www.scielo.br/scielo.php?script=sci_arttext\&pid=S0066$782 X 2009001200012 \& \operatorname{lng}=$ en\& $n r m=i s o>$.

5 Filgueiras Filho NM et al. Avaliação do conhecimento geral de médicos emergencistas de hospitais de Salvador - Bahia sobre o atendimento de vítimas com parada cardiorrespiratória. Arq. Bras. Cardiol., 2006 [acesso em 2012 abr 06]; 87(5) . Disponível em:

$<$ http://www.scielo.br/scielo.php?script=sci_arttext\&pid=S0066-

782 X2006001800014\&lng=en\&nrm=iso>.

6 Guimarães HP, Lane JC, Flato UAP et al. Uma breve história da ressuscitação cardiopulmonar. Rev Bras Clin Med, 2009 [acesso em 2012 abr 06]. Disponível em: $\langle$ http://www.ipatre.com.br/download/rcp-mundo.pdf $>$.

7 Bellan MC, Araujo IIM, Araujo S. Capacitação teórica do enfermeiro para o atendimento da parada cardiorrespiratória. Rev. bras. enferm., 2010 [acesso em 2012 abr 06]; 63(3). Disponível em: <http://www.scielo.br/scielo.php?script=sci_arttext\&pid=S0034$71672010000600023 \& \operatorname{lng}=$ en\&nrm=iso>.

8 Miotto HC et al. Efeito na Ressuscitação Cardiopulmonar utilizando treinamento teórico versus treinamento teórico-prático. Arq. Bras. Cardiol., 2010 [acesso em 2012 abr 06]; 95(3).

Disponível em: <http://www.scielo.br/scielo.php?script=sci_arttext\&pid=S0066782X2010001300008\&lng=en\&nrm=iso>.

9 Pergola AM, Araujo IEM. O leigo e o suporte básico de vida. Rev. esc. enferm. USP. 2009 [acesso em 2012 abr 06]; 43(2). Disponível em: $<$ http://www.scielo.br/scielo.php?script=sci_arttext\&pid=S0080$62342009000200012 \& \operatorname{lng}=\mathrm{en} \& \mathrm{nrm}=\mathrm{iso}>$. 
10 Miyadahira AMK et al. Ressuscitação cardiopulmonar com a utilização do desfibrilador externo semiautomático: avaliação do processo ensino-aprendizagem. Rev. esc. enferm. USP. 2008 [acesso em 2012 abr 06]; 42(3). Disponível em:

<http://www.scielo.br/scielo.php?script=sci_arttext\&pid=S0080$62342008000300017 \& \operatorname{lng}=$ en\&nrm=iso $>$.

11 Bertelli A, Bueno MR, Sousa RMC. Estudo preliminar das relações entre duração da parada cardiorrespiratória e suas consequências nas vítimas de trauma. Rev. esc. enferm. USP. 1999 [acesso em 2012 abr 06]; 33(2). Disponível em

$<$ http://www.scielo.br/scielo.php?script=sci_arttext\&pid=S0080$62341999000200004 \& \operatorname{lng}=$ en\&nrm=iso>.

12 Cereceda L. Orden de no reanimar, consideraciones sobre este problema. Rev. med. clin. condes, 2011 [acesso em 2012 abr 06]. Disponível em: <http://www.clc.cl/clcprod/media/contenidos/pdf/MED_22_3/369-376-dr-cereceda.pdf>.

13 Torres RVSD, Batista KT. A ordem de não ressuscitar no Brasil, considerações éticas. Com. Ciências Saúde. 2008 [acesso em 2012 abr 06]; 19(4). Disponível em: <http://www.fepecs.edu.br/revista/Vol19_4art01.pdf>.

14 Guyton AC, Hall JE. Tratado de fisiologia médica 10. ed. Rio de Janeiro: Guanabara Koogan, 2002.

15 Uenishi EK. Enfermagem médico-cirúrgica em unidade de terapia intensiva. 5. ed. São Paulo: SENAC, 2005.

16 Gomes AMCG, Timerman A, Souza CAM, Mendes CMC, Filho HPP, Oliveira AM, Souza JAA. Fatores prognósticos de sobrevida pós-reanimação cardiorrespiratória cerebral em hospital geral. Arq Bras Cardiol, 2005 [acesso em 2012 ago 24]; 85(4). Disponível em: <http://www.scielo.br/pdf/abc/v85n4/a06v85n4.pdf>.

17 Timerman et al. Prognóstico de ressuscitação cardiopulmonar. Arq Bras Cardiol, 2001. [acesso em 2012 jun 28]. Disponível em:

<http://publicacoes.cardiol.br/abc/2001/7702/7702006.pdf>.

18 AHA. Destaques das Diretrizes da American Heart Association 2010 para RCP e ACE. 2010. [acesso em 2012 abr 06] Disponível em: <http://www.heart.org/idc/groups/heartpublic/@wcm/@ecc/documents/downloadable/ucm_3 17343.pdf $>$.

19 Cruz Filho FES, Timerma NS, God EMG. Declaração de desfibrilação precoce. Arq. Bras. Cardiol., 1997 [acesso em 2012 jun 29]; 69(6). Disponível em: <http://www.scielo.br/scielo.php?script=sci_arttext\&pid=S0066782X1997001200013\&lng=en\&nrm=iso>.

20 Sampaio LABN. Avaliação do processo ensino-aprendizagem da técnica de ressuscitação cardiopulmonar pela equipe de enfermagem [tese]. São Paulo: Escola de Enfermagem, Universidade de São Paulo - Programa da EE/EERP, 185 p. 2003. 
21 Cesena F. Cardiologia sem fronteiras. [on line]. 2011. [acesso em 2012 jun 29]. Disponível em: <http://www.cardiologiasemfronteiras.com.br/2011/07/como-usar-o-desfibriladorexterno.html>.

22 Urban CA, Hoepers R, Silva IM, Júnior RAA. Implicações éticas das ordens de não ressuscitar. Rev Ass Med Brasil. 2001 [acesso em 2012 jun 20]; 47(3). Disponível em:< http://www.scielo.br/pdf/ramb/v47n3/6549.pdf>.

23 BRASIL. Decreto-lei n. 2.848, de 7 de dezembro de 1940. Estabelece critérios para prestação de socorro por profissionais da área de saúde. Diário Oficial da República Federativa do Brasil, Brasília, 31 dez. 1940. Seção 1, pt1. 126(302):23.911. 